\title{
On the Rich Agreement Hypothesis and Varieties of Embedded V2
}

\section{Hans-Martin Gärtner}

Abstract. This paper addresses the controversy between Koeneman \& Zeijlstra [K\&Z] (2014) and Heycock \& Sundquist [H\&S] (2017) concerning the viability of K\&Z's strong version of the "Rich Agreement Hypothesis" in the light of apparent counterexamples from the diachrony of Danish. It makes the general point that establishing whether or not cases of putative V-to-I movement in subordinate clauses can be reanalyzed as V-to-C, i.e., as "embedded Verb Second" [EV2], depends on the "EV2-type" of a language. The empirical discussion concerns appositve relatives and conditional protases, with $\mathrm{V}$-to-C in the former being in principle compatible with "narrow" $n E V 2$ as displayed by Modern Mainland Scandinavian languages, and V-to-C in the latter with Old Norse-style "broad" bEV2. It is concluded that the critical stages of Danish need to be scrutinized more closely before the above dispute can be settled.

Keywords. rich agreement, V-to-I, embedded verb second, assertion, appositive relatives, conditionals 


\section{OVERVIEW}

Koeneman \& Zeijlstra [K\&Z] (2014) "rehabilitate" the "Rich Agreement Hypothesis" along with its familiar diachronic prediction that loss of rich agreement triggers loss of V-to-I. In a critique of this approach, Heycock \& Sundquist [H\&S] (2017) argue that K\&Z fail to give a satisfactory account of the protracted time lag between these two processes in the history of Danish. H\&S point out that reanalysis of "unexpected" putative V-to-I as V-to-C, i.e., "embedded V2" [EV2] - the mechanism K\&Z propose to deal with such cases - is in conflict with the seemingly frequent occurrence of V-to-I in non-EV2-contexts during the critical historical stage(s) of Danish, as documented by Sundquist (2002; 2003).

In this paper, I argue that H\&S's conclusion may be premature, given that characterizations of the core diagnostic "EV2-hostile" environments differ when distinct varieties of EV2 are taken into account. In particular, "narrow" EV2 [ $\mathrm{nEV} 2]$, as familiar from the modern Mainland Scandinavian languages, confines EV2 to roughly speaking "assertion-friendly" contexts, while "broad" EV2 [bEV2], reported for certain varieties of Modern Icelandic and for Old Norse, has a wider distribution. A selective look at examples from Early Modern Danish that Sundquist (2002; 2003) categorizes as showing bona fide V-to-I reveals complications with both non-restrictive relatives and conditional clauses: The former arguably count as "EV2-friendly" environments even within an $n E V 2$ system and the latter do so within $b$ EV2, at least in Old Norse. Given evidence that Middle Danish possesses $b \mathrm{EV} 2$ (Vikner 1995), this paper must be taken as an appeal to revisit the historical facts from Early Modern Danish with an eye on its "EV2-type." The larger agenda promoted here concerns developing a better documentation and understanding of $b \mathrm{EV} 2$, which will make it possible to assess proposals like K\&Z's V-to-C reanalysis of V-to-I on firmer and independent theoretical grounds. 


\section{RICH AGREEMENT AND V-TO-I}

At least since the publication of works by Roberts (1985), Kosmeijer (1986), Platzack \& Holmberg (1989), and Rohrbacher (1994), richness of subject-verb agreement has been hypothesized to correlate with the presence vs. absence of syntactic V-to-I movement, i.e., movement of the verbal head of VP to the (abstract) head of IP. Among the core examples for this belongs the contrast between Modern Icelandic and Modern Mainland Scandinavian, here represented by Modern Swedish: The former, possessing "rich" agreement as shown in Table 1, requires V-to-I-movement, (1a)/(1b). ${ }^{1}$ The latter, lacking rich agreement as illustrated in Table 2, disallows V-to-I movement, (1c)/(1d).

\begin{tabular}{|c|c|c|c|}
\hline seg-ja 'say' & SG & PL & $i \rightarrow$ [+SPEAKER],[-PLURAL] \\
\hline $1 \mathrm{st}$ & seg-i & seg-jum & jum $\rightarrow$ [+SPEAKER],[+PLURAL] \\
\hline 2nd & seg-ir & seg-ið & ir $\rightarrow$ [-SPEAKER],[-PLURAL $]$ \\
\hline 3rd & seg-ir & seg-ja & ið $\rightarrow$ [-SPEAKER],[+PARTICIPANT],[+PLURAL] \\
\hline & & & $j a \rightarrow[$ [-PARTICIPANT],[+PLURAL] \\
\hline
\end{tabular}

Table 1. Modern Icelandic Agreement.

\begin{tabular}{|c|c|c|c|}
\hline säg-a 'say' & SG & PL & \\
\hline $1 \mathrm{st}$ & säg-er & säg-er & $e r \rightarrow$ [+FINITE $]$ \\
\hline 2nd & säg-er & säg-er & \\
\hline 3rd & säg-er & säg-er & \\
\hline
\end{tabular}

Table 2. Modern Swedish Agreement.

(1) a. ... hver stelpa [CP sem [IP Haraldur gaf ${ }_{i}\left[\mathrm{vP}\right.$ ekki [vp $t_{\boldsymbol{i}}$ bókina ]]]]

b. * ... hver stelpa [CP sem [IP Haraldur [vP ekki [vp gaf bókina ]]]]

c. * ... varje flicka [CP som [IP Harald $\operatorname{gav}_{\boldsymbol{i}}\left[\mathrm{VP}\right.$ inte [vP $t_{\boldsymbol{i}}$ boken ]]]]

d. ... varje flicka [CP som [IP Harald [vp inte [vp gav boken ]]]]

'each girl who Harald didn't give the book (to)' 
As can be seen in (1), the canonical syntactic diagnostic for V-to-I involves ordering of the finite verb relative to sentential negation within certain types of subordinate clauses. Determining the exact clausal environments involved is what this paper is about and I will come back to the matter momentarily.

The question as to how richness of verbal agreement should be characterized has been studied intensively (cf., e.g., Vikner 1997). Since precise detail is not crucial here, I present the relevant facts in the format provided by Koeneman \& Zeijlstra [K\&Z] (2014:576), whose approach to V-to-I will take center stage below. K\&Z's theory boils down to counting agreement as rich when a threshold of three person and two number values is reached. Thus, Modern Icelandic distinguishes [+SPEAKER] ("1st person"), [-SPEAKER][+PARTICIPANT] ("2nd person"), and [-PARTICIPANT] ("3rd person") in the person dimension, as well as [+PLURAL] and [-PLURAL] in the number dimension. Modern Swedish, on the other hand, doesn't make any such distinction and therefore misses the threshold for rich agreement. On the basis of this, K\&Z (2014:576) state a version of the "Rich Agreement Hypothesis" (RAH), which can be formulated as follows. ${ }^{2,3}$

\section{(2) The Rich Agreement Hypothesis (simplified)}

Language $L$ exhibits V-to-I movement if and only if $L$ possesses rich verbal agreement.

(2) itself, of course, is not new. Close variants of (2) have been formulated and been the subject of thorough debate over the years. In particular, as acknowledged by K\&Z, empirical evidence challenging both directions of (2) has been brought up: "language varieties that are poorly inflected but still display V-to-I movement (e.g., Jonas 1995 for Faroese, [...] Bentzen et al. 2007 for Regional Northern Norwegian varieties), as well as varieties that do not display obligatory V-to-I movement despite being richly inflected (e.g., Garbacz 2010 for Älvdalen 
Swedish)" (K\&Z 2014:571). As a consequence, the suggestion has been made to abandon the RAH entirely (Wiklund et al. 2007), ${ }^{4}$ or at least weaken it from a biconditional ("if and only if") to a conditional ("if"), such that rich agreement entails V-to-I but not vice versa (cf., e.g., Bobaljik \& Thráinsson 1998). It is therefore of high interest that - in full reversal of the above trend - K\&Z propose to "rehabilitate" the RAH and reinstall it "in its strongest, bidirectional form" (K\&Z 2014:572). This involves demonstrating ways in which challenges to the RAH can be met, and, importantly, some of the most intricate issues here concern the diachronic development of the Scandinavian languages. They will be focused on in the following discussion, which I hope to be able to contribute to a deeper understanding of the "diachronic consequences" of the RAH.

\section{THE RAH AND DIACHRONY}

Let me begin by citing K\&Z (2014:577), who themselves note that

[t]he RAH also predicts that changes in the verbal syntax and changes in the verbal paradigm should be closely related: morphological deflection should trigger the loss of V-to-I movement. This prediction is borne out. Take, for instance, Old Swedish [...] and Middle English [...]. Both are richly inflected [...]. Both display V-to-I movement, as expected [...].

At the same time, they address one of the major and most interesting challenges to the RAH (K\&Z 2014:606; cf. Vikner 1997: section 4.3):

it has been observed, as a critique of the RAH, that there can be a significant time gap between the loss of the relevant agreement inflection and the loss of V-to-I [...] movement.

The authors (K\&Z 2014:606) ${ }^{5}$ suggest that 
such time gaps are not at all problematic, however, since the input in those stages is still paradoxical, containing both input for a poor agreement paradigm and evidence for V-to-[I] movement.

More concretely, the idea is that the "paradox" will be resolved by standard mechanisms of language acquisition, the one of interest here being based on the assumption that "[...] the learner can [...] take the word order as primary" (K\&Z 2014:607). K\&Z claim that this is what happened in Faroese, where, as a consequence, "learners reanalyzed V-to-[I] movement as embedded V-to-C movement" (p. 607). This proposal, of course, rests on the well-known fact (cf., e.g., Holmberg 1986:112) that, in languages with "medial" Iº standard cases of bona fide V-to-I, (3a), and subject-initial "embedded V2" (EV2) clauses, ${ }^{6}$ (3b), are string-identical. ${ }^{7}$

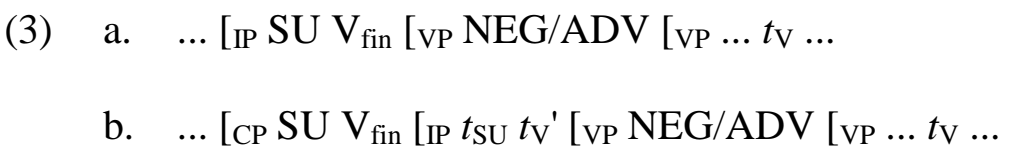

In a recent critique of K\&Z (2014), Heycock \& Sundquist [H\&S] (2017:175 fn.1) rightly point out that "the evidence for this reanalysis in Faroese is largely circumstantial, given the gap in the documentary evidence for Faroese between the medieval period and the late 18th century." Thus, to make a better case for a reanalysis of V-to-I as EV2, one has to tackle more thoroughly documented cases, such as Danish and Swedish. The former is directly addressed by H\&S (2017:173-174): ${ }^{8}$

Sundquist (2002; 2003) shows that while by 1350 there was at most a singular/plural distinction encoded in the verbal morphology of Middle Danish, V-to-I is still evidenced robustly in the data for more than two centuries after that date. In texts from the first half of the 16th century - two 
hundred years after the morphology has become "poor" by the definition in $\mathrm{K} \& \mathrm{Z}-\mathrm{V}$-to-I appears at a rate of $42 \%$. In fact, even in [...] the second half of the 17th century, it still occurs at a rate of above 10\% (Sundquist 2003:242).

And, importantly, H\&S (2017:175) directly dismiss the option of V-to-C-reanalysis, stating that "[t]his explanation for the persistence of V-Neg/Adv orders in Danish was [...] already ruled out in Sundquist (2002; 2003)."

\section{VARIETIES OF EV2}

Although I think that the point H\&S (2017) make is largely valid, I will argue that certain difficulties in teasing apart EV2 and V-to-I may blur their results and make arguments against K\&Z's proposal less conclusive.

To begin with, it is clear that in order to rule out V-to-C reanalysis one needs to find instances of bona fide V-to-I. In the core case, this requires identifying environments where pattern (3a) occurs but (3b) is blocked. Let us call such environments "EV2-hostile." The latter are standardly characterized ex negativo, i.e., via providing criteria for "EV2-friendly" environments. However, two things stand in the way of making this an easy task. First, there is so far no fully satisfactory theory of the distribution of EV2. And, second, it is clear that the boundary between EV2-hostile and EV2-friendly environments can shift both across languages and diachronically. The interdependence of these issues makes it necessary to address them together.

\subsection{Narrow vs. Broad EV2}

At least for the modern Mainland Scandinavian languages, a fairly solid characterization of EV2-friendly environments can build on work by, among others, Andersson (1975) and Wechsler (1991) and identify them - as long as we are dealing with declarative clauses - with 
"assertion-friendly" environments. This means that the content of the V2-clause counts as something the speaker actively commits to and as intended to enrich the common ground (cf., e.g., Wiklund 2010:87). In addition, provisos have to be made to include "derivative" (or "shifted") uses of EV2 in speech and thought representation. ${ }^{9}$

Now, as is well-known, there are varieties of Modern Icelandic where EV2 shows a broader distribution, as exemplified in (4b) (Rögnvaldsson \& Thráinsson 1990:23) and contrasted with Modern Swedish, (4a) (cf. Hrafnbjargarson \& Wiklund 2009:33).
(4) a. * Johan tvivlar på [CP att [CP i morgon skall [IP Maria gå upp tidigt ]]]
b. Jón efast um [СР að [СР á morgun fari [IP María snemma á fætur ]]]
'John doubts that Mary will get up early tomorrow'

Clearly, given the meaning of "to doubt", Mary's getting up early on the next day is nothing the speaker commits to (via an utterance of (4)), nor does it correspond to the content of John's thought (or speech). Yet, EV2 is possible in Icelandic here, instantiated by non-subjectinitial V2, the hallmark of bona fide V-to-C. Let us call the distribution of EV2 where EV2friendly and "assertion-friendly" environments coincide "narrow EV2" [nEV2] and the extended one displayed by certain varieties of Modern Icelandic "broad EV2" [bEV2]. ${ }^{10}$ From these brief and sketchy considerations we can already see that the adequacy of K\&Zstyle V-to-C reanalysis of V-to-I depends on the EV2-type - $n E V 2$ or $b E V 2$ - of the language(s) in question. This is what will be addressed next.

\section{V-TO-C REANALYSIS}

Sundquist's crucial observation, on which H\&S (2017) build their assessment that V-to-C reanalysis of V-to-I is excluded for Danish, concerns the absence of any drop in "frequency of 
V-Neg/Adv orders" in EV2-hostile environments. However, the method of identifying such environments is neither very elaborate (cf. Garbacz, Håkansson \& Rosenkvist 2007) nor does it take into account the difference between $n \mathrm{EV} 2$ and $b \mathrm{EV} 2$. As summarized by $\mathrm{H} \& \mathrm{~S}$ (2017:175),

[i]n order to control for the possibility that the high position for the verb in his data was due to EV2 rather than V-to-I, Sundquist isolated the cases that did not occur in an embedded declarative (operationalized as a clause introduced by the complementizer at 'that').

[EV2] is excluded - or at best highly disfavored - in relative clauses, indirect questions, and most types of adverbial clauses [...].

Now, among the clause types actually presented by Sundquist (2002; 2003) as displaying bona fide V-to-I, relatives and conditionals figure prominently. Let us discuss each type in turn.

\subsection{Relative Clauses}

Quite strikingly, the two instances of relative clauses that Sundquist (2002:298) provides as evidence for Early Modern Danish V-to-I are both non-restrictive or "appositive." They are given as the underlined parts with their fuller contexts in (5) and (6). ${ }^{11}$ 
(5) Jeg erindrer mig om de dejlige Lunde wed Ketting,

I remember me about the beautiful groves near Ketting hwor jeg gich alltijd och spatzerede, hwor jeg brød min Arm where I went always and walked where I broke my arm och falt af Hesten [...] and fell from horse.the

'I remember the beautiful groves near Ketting, where I always went walking, where I broke my arm and fell off the horse ...'

(6) Udj hindis lidet Cammer, som waar inden for dend Stue, out.in her small chamber REL was inside of that living.room hindis s. Moder laae i, och som JomfruHelle Lyche waar alltijd hoß, her late mother lay in and REL Miss Helle Lyche was always with passerede jeg heele Efftermiddagene

spent I all afternoons.the

'In her small chamber, which was next to the living room her late mother lay in, who Miss Helle Lyche was always with, I passed all afternoons.'

That the author always went for walks there, (5), and that Miss Helle Lyche always was with her, (6), is additional information about independently established referents: the beautiful groves near Ketting in (5), and Miss Helle Lyche's late mother in (6). This information meets the criteria for assertion in being actively committed to by the speaker/author and intended to enrich the common ground. Consequently, appositive relative clauses (ARCs) would have to be considered EV2-friendly environments even in (the more limited) $n E V 2$ systems (Section 4.1). ${ }^{12}$ Further empirical evidence for this comes, among other things, from the ease with 
which speech act sensitive items like modal particles and the performative marker hereby can be inserted into ARCs (cf. Andersson 1975:69, 74, for Swedish; and Reis 2006: section 3.1, for German). What is more, Modern English, which can be considered to possess "residual" $n \mathrm{EV} 2$, allows subject-auxiliary inversion [SAI] - standardly analyzed as (non-subject-initial) V-to-C - in ARCs (Hooper \& Thompson 1973:472):

(7) Hal, who under no circumstances would I trust, asked for a key to the vault

Thus, further technicalities aside, ${ }^{13}$ a V-to-C analysis of the putative V-to-I cases in (5) and (6) may have to be envisaged:

(8) a. [CP hwor $\boldsymbol{k} \varnothing\left[\mathrm{CP}_{\text {jeg }}\right.$ gich $_{i}\left[\mathrm{IP} t_{j} t_{i}^{\prime}\left[\mathrm{VP}\right.\right.$ alltijd [VP $\left.\left.\left.\left.t_{i} t_{k}\right]\right]\right]\right]$

b. [CP $O p_{k}$ som [CP Jomfru Helle Lyche waar $_{i}\left[\mathrm{IP} t_{j} t_{i}{ }^{\prime}\right.$ [vP alltijd [vP $t_{i}$ hoß $t_{k}$ ]]]]

The case against K\&Z's proposal of V-to-C reanalysis would therefore be strengthened by minimizing reliance on ARCs as evidence.

Two caveats are in order here. One concerning ARCs in general, the other regarding (5) and (6) in particular. As for the former, ARCs in full-fledged modern Germanic V2-languages differ from their Modern English counterparts in (7) in disallowing EV2. (9) illustrates this for the direct translation of (7) into German. ${ }^{14}$

(9) *Hal, dem unter keinen Umständen würde ich vertrauen, fragte nach einem Schlüssel zum Keller 
The discrepancy between apparent EV2-hostility and existence of the earlier mentioned markers of "assertion-friendliness" is one of the main points raised by Reis (2006) against simplistic assertion-based definitions of EV2-friendly environments for $n E V 2$-languages. The same tension is also indirectly noted by Andersson (1975:69), who points out the necessity of finite verbs in Modern Swedish to follow modal particles like ju ('as you know', 'obviously') analyzed as instantiating VP-attached ADV in (3) - in ARCs. ${ }^{15}$

(10) Igår träffade jag Eva, som du (ju) känner (*ju) bättre än jag

'Yesterday I met Eva, who you (obviously) know better than I.'

If these facts are taken as default property of $n E V 2$-systems, an alternative characterization of EV2-friendly environments has to be found for such systems that excludes ARCs. ${ }^{16}$ Thus, if H\&S's critique of $K \& Z$ is to eventually be put on a principled basis, a simple case by case listing of EV2-hostile clause types is unsatisfactory.

The second caveat concerns the diagnostic status of alltijd ('always'), which occurs in both (5) and (6). Falk (1993:171-172) provides evidence from earlier varieties of Swedish that adverbs differ from sentential negation in allowing lower attachment inside VP. ${ }^{17}$ (5) and (6) might therefore instantiate an alternative to the patterns in (3), shown in (11), with short verb movement within a layered vP/VP:

$$
\ldots\left[\mathrm { IP } S \mathrm { I } ^ { \circ } { } _ { \mathrm { v } p } t _ { \mathrm { SU } } \mathrm { V } _ { \mathrm { fin } } \left[\mathrm { vP } \mathrm { ADV } \left[\mathrm{vP} \ldots t_{\mathrm{V}} \ldots\right.\right.\right.
$$

This is what K\&Z (2014:586) propose to meet related putative challenges from Regional Northern Norwegian and Kronoby Swedish to the RAH (cf. Wiklund et al. 2007). Crucially, 
$\mathrm{V}_{\text {fin }}>\mathrm{ADV}$-orders of this kind are no reliable indicator of $\mathrm{V}$-to-I and thus the question of violating the RAH would not arise for (5)/(6) independently of EV2-reanalyzability. ${ }^{18}$

\subsection{Conditional Clauses}

Consider the underlined conditional (protasis) in (12), offered by Sundquist (2002:297) as another instance of V-to-I in Early Modern Danish.

(12) her Per vell mett ted snareste selff drage tyl k.m.,

Mr. Per wants with the soonest himself go to Royal.Majesty

om vy for icke de suar, oss behaffwer

if we get not those answers us please

'Mr. Per wants to go to His Royal Majesty as soon as possible himself, if we don't receive the answers we desire.'

That the author and her husband receive the answers they desire is not asserted here. Nor is it a "premise" in the sense of Haegeman (2003), who shows that "premise conditionals" may host "main clause phenomena" in English. ${ }^{19}$ Thus, if Early Modern Danish possesses $n E V 2$, the conditional in (12) constitutes an EV2-hostile environment and a V-to-I analysis is indeed called for.

However, importantly, conditionals belong among the evidence in favor of taking older stages of Scandinavian to possess $b$ EV2. This is exemplified for Old Icelandic in (13). ${ }^{20}$ 


\begin{abstract}
(13) Dalla kvað mannamun mikinn og pó eigi víst Dalla said difference.of.men great and even not certain að til yndis yrði $\quad$ ef petta vissi Dorkell í Tungu that to happiness would.become if that knew Thorkel in Tunga 'Dalla said there was a mighty great difference betwixt them, and it was far from certain to end happily if Thorkel of Tunga got to know'
\end{abstract}

Again, we can assume to be dealing with a standard "hypothetical" conditional, which renders this an EV2-hostile enviroment under $n E V 2$. The possibility of non-subject-initial EV2 in (13) thus indicates the kind of extension of EV2-friendly environments characteristic of $b$ EV2. By contrast, the unacceptability of counterparts of (13) in Modern Danish (Vikner 1995:160) conforms with the standard assumption that the modern Mainland Scandinavian languages have $n \mathrm{EV} 2 .^{21}$

We can infer from this very brief look at conditionals that examples like (13) only constitute evidence against K\&Z's V-to-C reanalysis proposal for Danish if Early Modern Danish can be assumed to be an $n E V 2$ system like Modern Danish, rather than a $b E V 2$ system. That this is not a priori clear is suggested by observations about Middle Danish, the immediately preceding historical stage, at which according to H\&S (2017) agreement already counts as poor by the standards of the RAH (see Sections 2 and 3 above). Thus, the following Middle Danish counterpart of (13), i.e., a hypothetical conditional displaying the critical pattern in (3) has been presented by Bentzen \& Hróarsdóttir (2009:128; citing Hrafnbjargarson 2004:212). ${ }^{22}$

(14) vm min man hafvir inkte rætfongit gooz hwat skal iac ædaællas drikkia if my man has not rightly.received goods what shall I eat or drink 'If my husband doesn't have rightfully acquired goods, what shall I eat or drink?' 
At the same time, on the basis of the som-equative in (15), Middle Danish has been argued by Vikner (1995:160) to display $b \mathrm{EV} 2 .^{23}$

(15) hans low skal een suygæ thøm, saa som nu giør Iødernæ low his law shall yet fail them so as now does Jews.the.GEN law 'His [= Mohammed's] law shall fail them, as does the Jews' law now.'

It has to be stressed, though, that what we have here is only "circumstantial evidence." A more thorough reassessment of Early Modern Danish EV2 is required for establishing its EV2-type.

\subsection{V-to-C Reanalysis and EV2-Types}

Abstractly, the situation can be summarized as follows. Assume that a language possesses Vto-I in all "embedded" clause types. As depicted in Figure 1, V-to-C reanalysis, which in the core case means transition from structures like (3a) to structures of type (3b) (Section 3), implies avoidance of EV2-hostile environments (here marked as shaded areas).

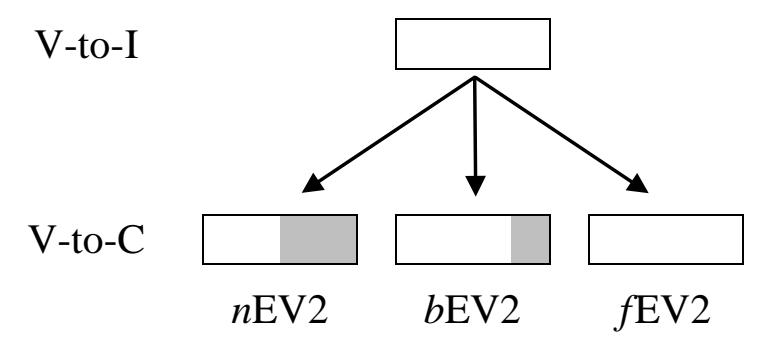

Figure 1. V-to-C Reanalysis and EV2-Types

The distributional consequences of this avoidance, however, depend on the EV2-type of the language at the stage of the reanalysis. If the language possesses "free EV2" [fEV2], i.e., a (hypothetical) type where all environments are EV2-friendly, there would be no observable 
consequences. The strings representing pattern (3) would continue to occur in all embedded environments. If, by contrast, we are dealing with an $n E V 2$ system, such strings will be confined to "assertion-friendly" environments. Finally, under $b E V 2$ we end up somewhere in between. The EV2-friendly region is expanded without constituting an "anything goes." Thus, to repeat, in order to settle the case for or against K\&Z's V-to-C reanalysis of V-to-I, one needs to establish the EV2-type of the language in question at the historical stage the reanalysis is supposedly taking place.

\section{BROAD EV2}

From the discussion so far we can conclude that an important step toward a defense of K\&Z's V-to-C reanalysis approach would consist in showing that Danish was a $b$ EV2 system at the stage(s) where putative V-to-I configurations continued to occur in the absence of rich verbal agreement. If that were possible, a follow-up step would have to consist in arguing on independent theoretical grounds that V-to-C is the correct analysis in all of the controversial cases. However, given (i) the doubly negative characterization of $b \mathrm{EV} 2$ - broader than $n \mathrm{EV} 2$ but narrower than $f \mathrm{EV} 2$ - and (ii) the still only partially understood nature of $n \mathrm{EV} 2$ (Section 4.1), it may be difficult to make any further progress fast. Since it is impossible to do justice to the intricacies of this within the confines of this paper, I'll leave the topic for further research. Instead, I'll conclude by briefly revisiting an approach to $b \mathrm{EV} 2$ that links it back to the RAH.

\subsection{Broad EV2 and Rich Agreement}

Holmberg \& Platzack (1995: section 3.4.3.-3.4.6.) analyze EV2 in terms of "CP-recursion" (cf., e.g., Vikner 1995; and Vikner 2017a, for recent revisions), where the difference between $n E V 2$ in modern Mainland Scandinavian and $b E V 2$ in Modern Icelandic and Old Norse 
hinges on the absence vs. presence of an additional finiteness feature $[+F]$ on the outer $\mathrm{C}^{\circ}$ (p.84). This is schematically shown in $(16 a) /(16 b)$, corresponding to the relevant parts of $(4 a) /(4 b)$, respectively.

(16) a.

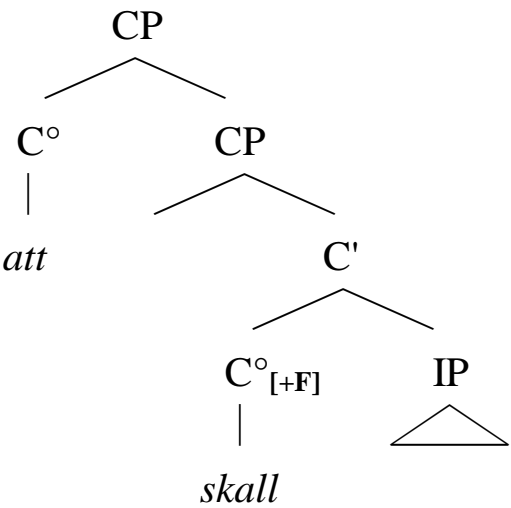

b.

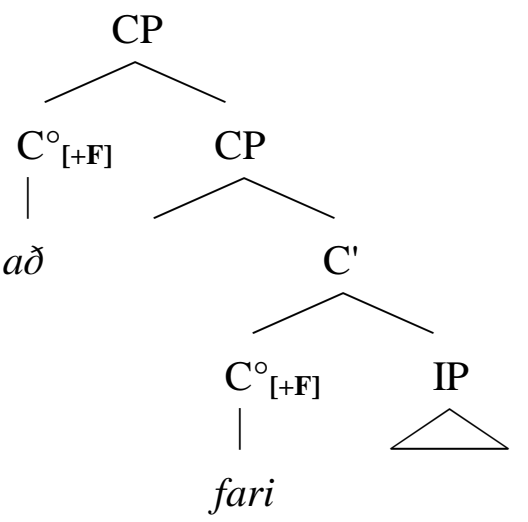

Crucially, the additional $[+\mathrm{F}]$ is licensed "only in a language with nominative Agr" (p.84), that is, a language with rich verbal agreement. Secondly, lexicalization of $[+F]$ by the finite verb is assumed to trigger "main clause interpretation" (p.86), which confines the EV2clauses in question to "assertion-friendly" environments. This is what enforces $n E V 2$ for languages lacking rich agreement like Swedish, as exemplified in (16a)/(4a). Lexicalization of [+F] by a complementizer results in a standard subordinate clause, compatible with whatever semantics subordination requires. Where both types of lexicalization cooccur as in (16b), the outer specification wins out and "main clause interpretation" triggered by V-to-C is suspended (p.86). This allows EV2-clauses in languages with rich agreement like Icelandic, (16b)/(4b), to behave like ordinary subordinate clauses, which is the basis for $b \mathrm{EV} 2$.

Turning to the diachronic consequences of the above account, we can notice that the RAH becomes part of a larger "conspiracy." Loss of rich agreement not only results in loss of V-toI (cf. also Holmberg \& Platzack 1995:77) but in addition it comes with a switch from $b$ EV2 to $n E V 2$, as summarized in (17). 
(17) rich agreement \& V-to-I \& bEV2

$\Downarrow$

poor agreement \& V-in-situ \& $n \mathrm{EV} 2$

This immediately predicts that K\&Z's V-to-C reanalysis of putative "late" V-to-I should occur in an $n E V 2$ context. Thus, the strategy of accounting for verb positioning in, for example, conditionals like (12) by postulating the relevant historical stage of the language to display $b E V 2$ would no longer work.

However, the close link in (17) is dubious for the simple reason that - as already hinted at in Section 4.1 - in Modern Icelandic bEV2 is found only in certain varieties. On the whole, Modern Icelandic shows variation between $b \mathrm{EV} 2$ and $n \mathrm{EV} 2$ (Jónsson 1996:39). At the same time, all varieties of Modern Icelandic continue to possess both rich agreement and V-to-I. Likewise, the combination of poor agreement and $b \mathrm{EV} 2$ may exist in some varieties of Modern Norwegian, where, according to the survey by Bentzen (2014), counterparts of (4b) were found acceptable. Similarly, the combination seems to show up in Middle Danish, as indicated at the end of Section 5.2. ${ }^{24}$

\section{CONCLUSION}

As part of their "rehabilitation" of the "Rich Agreement Hypothesis" [RAH], Koeneman and Zeijlstra [K\&Z] (2014) subscribe to a close diachronic correlation between loss of rich agreement and loss of V-to-I. They propose to meet the familiar challenge of a protracted time lag between loss of agreement and loss of V-to-I (cf., e.g., Vikner 1997) by a number of reanalysis mechanisms, reanalysis of V-to-I as V-to-C, i.e., as "embedded V2" [EV2], being the one focused on here. In a critique of K\&Z's approach, Heycock and Sundquist [H\&S] 
(2017) point out that V-to-C reanalysis is not an option in the case of Danish, for which Sundquist (2002; 2003) expressly sought to identify instances of V-to-I in non-EV2 environments at the relevant historical stage(s).

In this short paper, I have argued that settling the case for or against V-to- $\mathrm{C}$ reanalysis requires carefully taking into account the "EV2-type" of the languages under investigation. In particular, the familiar "narrower" distribution of EV2 [nEV2] in modern Mainland Scandinavian - confined to roughly speaking "assertion-friendly" environments - is known to contrast with a "broader" distribution [bEV2] in certain varieties of Modern Icelandic and Old Norse. As a consequence, the borderline between "EV2-hostile" and "EV2-friendly" environments varies.

By way of illustration, I have raised concerns about some examples from Early Modern Danish that Sundquist (2002; 2003) classifies as bona fide V-to-I. First, among relative clauses, non-restrictives must be handled with care, since, encoding "secondary" assertions, they would constitute EV2-friendly environments even within the more limited $n E V 2-t y p e .{ }^{25}$ Second, "hypothetical" conditionals, which must be considered EV2-hostile under $n \mathrm{EV} 2$, have been shown to constitute EV2-friendly environments in (Old Norse) bEV2. Thus, putative V-to-I in such conditionals would resist K\&Z-style V-to-C reanalysis only if the historical stage of the language in question counts as $n E V 2$. This may not hold for Middle Danish, where evidence for $b E V 2$ has been provided. The EV2-type of Early Modern Danish needs to be investigated.

Let me stress that I've chosen to focus on cases problematic for $\mathrm{H} \& \mathrm{~S}$ in order to make a methodological point about the importance of distinguishing EV2-types. ${ }^{26}$ Thus, even if it can be shown that both Middle Danish and Early Modern Danish possess bEV2, V-to-C reanalysis of the entire set of putative V-to-I cases in those languages will have to be argued to be the correct approach on independent theoretical grounds. What's more, given the doubly 
negative characterization of $b \mathrm{EV} 2$ - broader than $n \mathrm{EV} 2$ but narrower than an entirely unconstrained "free" EV2 [fEV2] - and the still only partially understood nature of "assertion-friendly" environments as basis for $n \mathrm{EV} 2$ (Section 4.1), no firm conclusions about the controversy can be drawn. Instead, a much more careful study of (varieties of) EV2 in the history of Scandinavian seems to be called for.

\section{ACKNOWLEDGMENTS}

I am grateful to three anonymous reviewers, the editors of this volume, as well as Johan Brandtler, Dórhallur Eybórsson, Cecilia Falk, Caroline Heycock, Jóhannes Gísli Jónsson, John Sundquist, and Sten Vikner for advice, comments, and criticisms at various stages of the research reported on here. I would also like to thank the audiences at the workshop on "Morphological Effects on Word Order from a Typological and a Diachronic Perspective" (DGfS Konstanz; February 2016), the Departments of Linguistics at Wuppertal University and Cambridge University (March 2016), the Budapest-Potsdam-Lund Colloquium (Budapest, June 2016), and the workshop on Scandinavian syntax at the University of the Faroe Islands at Tórshavn (February 2017). I acknowledge support by the National Research, Development and Innovation Office (NKFIH) (project number K115922). Common disclaimers apply.

\section{REFERENCES}

Andersson, Lars-Gunnar. 1975. Form and Function of Subordinate Clauses. Ph.D. Dissertation, Göteborg University.

Angantýsson, Ásgrímur. 2007. Verb-Third in Embedded Clauses in Icelandic. Studia Linguistica 61(3), 237-260.

Angantýsson, Ásgrímur. 2011. The Syntax of Embedded Clauses in Icelandic and Related Languages. Ph.D. Dissertation, University of Iceland. 
Antomo, Mailin. 2016. Marking (Not-)at-Issue Content by Using Verb-Order Variation in German. In Ingo Reich \& Augustin Speyer (eds.), Co- and Subordination in German and Other Languages, 21-54. Hamburg: Buske.

Bentzen, Kristine. 2014. Embedded Verb Second (V2). Nordic Atlas of Language Structures Journal 1, 211-224.

Bentzen, Kristine. 2014. Verb Placement in Relative Clauses. Nordic Atlas of Language Structures Journal, 1, $240-249$.

Bentzen, Kristine \& Thorbjörg Hróarsdóttir. 2009. Stepwise Loss of Verb Movement. In Rajat Mohanty \& Mythili Menon (eds.), Universals and Variation, 117-138. Hyderabad: The EFL University Press.

Bobaljik, Jonathan \& Höskuldur Thráinsson. 1998. Two Heads Aren't Always Better Than One. Syntax 1(1), 37-71.

Chierchia, Gennaro \& Sally McConnell-Ginet. 1990. Meaning and Grammar. An Introduction to Semantics. Cambridge, MA: MIT Press.

Collingwood, William \& Jón Stefánsson. 1902. The Life and Death of Cormac the Skald. (Viking Club Translation Series, No. 1.) Ulverston: Holmes.

Coniglio, Marco. 2011. Die Syntax der deutschen Modalpartikeln. Berlin: Akademie Verlag.

Djärv, Kajsa, Caroline Heycock \& Hannah Rohde. 2017. Assertion and Factivity: Towards Explaining Restrictions on Embedded V2 in Scandinavian. In Laura Bailey \& Michelle Sheehan (eds.), Order and Structure in Syntax I: Word Order and Syntactic Structure, 3-28. Berlin: Language Science Press.

Faarlund, Jan Terje. 2004. The Syntax of Old Norse. Oxford: OUP.

Falk, Cecilia. 1993. Non-Referential Subjects in the History of Swedish. Ph.D. Dissertation, Lund University.

Falk, Cecilia. 2007. Kilkonstruktion och ordföljd i äldre fornsvenska. In Lars Wollin, Anna Saarukka \& Ulla Stroh-Wollin (eds.), Svenska språkets historia, 9, 90-98. Åbo: Åbo Akademi.

Garbacz, Piotr, David Håkansson \& Henrik Rosenkvist. 2007. Review of 'Morphosyntactic Change in the History of the Mainland Scandinavian Languages' by John Sundquist. Nordic Journal of Linguistics 30(1), 137-146.

Gärtner, Hans-Martin. 2001. Are There V2 Relative Clauses in German? Journal of Comparative Germanic Linguistics, 3, 97-141. 
Gärtner, Hans-Martin \& Pórhallur Eypórsson. to appear. Varieties of Dependent V2 and Verbal Mood: A View from Icelandic. In Theresa Biberauer, Sam Wolfe \& Rebecca Woods (eds.), Rethinking Verb Second. Oxford: OUP.

Gärtner, Hans-Martin \& Jens Michaelis. 2010. On Modeling the Distribution of Declarative V2-Clauses: the Case of Disjunction. In Sebastian Bab \& Klaus Robering (eds.), Judgements and Propositions, 11-25. Berlin: Logos.

Gärtner, Hans-Martin \& Jens Michaelis. to appear. V2-Declaratives, Assertion, and Disjunction Revisited. In Theresa Biberauer, Sam Wolfe \& Rebecca Woods (eds.), Rethinking Verb Second. Oxford: OUP.

de Haan, Germen. 2001. More is Going on Upstairs than Downstairs: Embedded Root Phenomena in West Frisian. Journal of Comparative Germanic Linguistics 4(1), 3-38.

Haegeman, Liliane. 2003. Conditional Clauses: External and Internal Syntax. Mind \& Language 18(4), 317-339.

Harbour, Daniel. 2015. Poor Pronoun Systems and What They Teach Us. Nordlyd 40(1), 125-143.

Heycock, Caroline \& John Sundquist. 2017. Don’t Rush to Rehabilitate: A Remark on Koeneman \& Zeijlstra 2014. Linguistic Inquiry 48(1), 173-179.

Heycock, Caroline \& Joel Wallenberg. 2013. How Variational Acquisition Drives Syntactic Change. The Loss of Verb Movement in Scandinavian. Journal of Comparative Germanic Linguistics 16(2-3), 127-157.

Holmberg, Anders. 1986. Word Order and Syntactic Features in Scandinavian Languages and English. Stockholm: University of Stockholm.

Holmberg, Anders. 2006. Stylistic Fronting. In Martin Everaert \& Henk van Riemsdijk (eds.), The Blackwell Companion to Syntax, IV, 532-565. Oxford: Blackwell.

Holmberg, Anders \& Christer Platzack. 1995. The Role of Inflection in Scandinavian Syntax. Oxford: OUP.

Hooper, Joan B. \& Sandra A. Thompson. 1973. On the Applicability of Root Transformations. Linguistic Inquiry 4(4), 465-497.

Hrafnbjargarson, Gunnar Hrafn. 2004. Oblique Subjects and Stylistic Fronting in the History of Scandinavian and English. The Role of IP-Spec. Ph.D. Dissertation, University of Aarhus.

Hrafnbjargarson, Gunnar Hrafn \& Anna-Lena Wiklund. 2009. General Embedded V2: Icelandic A, B, C etc. Working Papers in Scandinavian Syntax 84, 21-51.

Jónsson, Jóhannes Gísli. 1996. Clausal Architecture and Case in Icelandic. Ph.D. Dissertation, University of Massachusetts at Amherst.

Julien, Marit. 2015. The Force of V2 Revisited. Journal of Comparative Germanic Linguistics 18(2), 139-181. 
Koeneman, Olaf \& Hedde Zeijlstra. 2014. The Rich Agreement Hypothesis Rehabilitated. Linguistic Inquiry 45(4), 571-615.

Koev, Todor. 2013. Apposition and the Structure of Discourse. Ph.D. Dissertation, Rutgers University.

Kosmeijer, Wim. 1986. The Status of the Finite Inflection in Icelandic and Swedish. Working Papers in Scandinavian Syntax 26, 1-41.

Nygaard, Marius. 1905. Norrøn Syntax. Kristiania: Aschehoug.

Platzack, Christer \& Anders Holmberg. 1989. The Role of AGR and Finiteness. Working Papers in Scandinavian Syntax 43, 51-76.

Potts, Christopher. 2005. The Logic of Conventional Implicatures. Oxford: OUP.

Reis, Marga. 1997. Zum syntaktischen Status unselbständiger Verbzweit Sätze. In Christa Dürscheid (ed.), Sprache im Fokus, 121-144. Tübingen: Niemeyer.

Reis, Marga. 2006. Is German V-to-C Movement Really Semantically Motivated? Some Empirical Problems. Theoretical Linguistics 32(3), 369-380.

Rizzi, Luigi. 1997. The Fine Structure of the Left Periphery. In Liliane Haegeman (ed.), Elements of Grammar, 281-337. Dordrecht: Kluwer.

Rizzi, Luigi. 2001. Relativized Minimality Effects. In Mark Baltin \& Chris Collins (eds.), The Handbook of Contemporary Syntactic Theory, 89-110. Oxford: Blackwell.

Roberts, Craige. 1996. Information Structure in Discourse: Towards an Integrated Formal Theory of Pragmatics. OSU Working Papers in Linguistics 49, 91-136.

Roberts, Ian. 1985. Agreement Parameters and the Development of English Modal Auxiliaries. Natural Language and Linguistic Theory 3(1), 21-58.

Roberts, Ian. 1993. Verbs and Diachronic Syntax. A Comparative History of English and French. Dordrecht: Kluwer.

Rohrbacher, Bernhard. 1994. The Germanic VO Languages and the Full Paradigm. A Theory of V to I Raising. Ph.D. Dissertation, UMass at Amherst.

Rögnvaldsson, Eiríkur \& Höskuldur Thráinsson. 1990. On Icelandic Word Order Once More. In Joan Maling \& Annie Zaenen (eds.), Syntax and Semantics 24, 3-40. New York: Academic Press.

Roll, Mikael. 2006. Prosodic Cues to the Syntactic Structure of Subordinate Clauses in Swedish. In Gösta Bruce \& Merle Horne (eds.), Nordic Prosody, 195-204. Frankfurt/M.: Peter Lang. 
Roll, Mikael, Merle Horne \& Magnus Lindgren. 2009. Left-Edge Boundary Tone and Main Clause Verb Effects on Syntactic Processing in Embedded Clauses - An ERP Study. Journal of Neurolinguistics 22(1), 55-73.

Schlenker, Philippe. 2018. The Semantics and Pragmatics of Appositives. Unpublished manuscript, Institut JeanNicod, CNRS.

Sigurðsson, Halldór. 1986. Verb Post-Second in a V2 Language. In Östen Dahl \& Anders Holmberg (eds.), Scandinavian Syntax, 138-149. Stockholm: University of Stockholm.

Sundquist, John. 2002. Morphosyntactic Change in the History of the Mainland Scandinavian Languages. Ph.D. Dissertation, Indiana University.

Sundquist, John. 2003. The Rich Agreement Hypothesis and Early Modern Danish Embedded-Clause Word Order. Nordic Journal of Linguistics 26(2), 233-258.

Syrett, Kristen \& Todor Koev. 2015. Experimental Evidence for the Truth Conditional Contribution and Shifting Information Status of Appositives. Journal of Semantics 32(3), 525-577.

Thráinsson, Höskuldur. 2010. Predictable and Unpredictable Sources of Variable Verb and Adverb Placement in Scandinavian. Lingua 120(5), 1062-1088.

Thráinsson, Höskuldur. 2011. Icelandic A, B, C, D ...? Or: How Long is the Icelandic Alphabet?. Talk presented at DGfS 33, Göttingen University.

Tvica, Seid. 2017. Agreement and Verb Movement. The Rich Agreement Hypothesis from a Typological Perspective. Ph.D. Dissertation, University of Amsterdam.

Vikner, Sten. 1995. Verb Movement and Expletive Subjects in the Germanic Languages. Oxford: OUP.

Vikner, Sten. 1997. Vº-to-I Movement and Inflection for Person in All Tenses. In Liliane Haegeman (ed.), The New Comparative Syntax, 189-212. London: Longman.

Vikner, Sten. 2017a. CP-Recursion and the Derivation of Verb Second in Germanic Main and Embedded Clauses. In Constantin Freitag, Oliver Bott \& Fabian Schlotterbeck (eds.), Two Perspectives on V2, 1-26. Konstanz: Konstanz University.

Vikner, Sten. 2017b. Object Shift in Scandinavian. In Martin Everaert \& Henk van Riemsdijk (eds.), The Wiley Blackwell Companion to Syntax, 2784-2844. Hoboken, NJ: John Wiley \& Sons.

Wechsler, Stephen. 1991. Verb Second and Illocutionary Force. In Katherine Leffel \& Denis Bouchard (eds.), Views on Phrase Structure, 177-191. Dordrecht: Kluwer.

Wiklund, Anna-Lena. 2010. In Search of the Force of Dependent Verb Second. Nordic Journal of Linguistics 33(1), 81-91. 
Wiklund, Anna-Lena, Kristine Bentzen, Gunnar Hrafn Hrafnbjargarson \& Thorbjörg Hróarsdóttir. 2009. On the Distribution and Illocution of V2 in Scandinavian that-Clauses. Lingua 119(12), 1914-1938.

Wiklund, Anna-Lena, Gunnar Hrafn Hrafnbjargarson, Kristine Bentzen \& Thorbjörg Hróarsdóttir. 2007. Rethinking Scandinavian Verb Movement. Journal of Comparative Germanic Linguistics 10(3), 203-233.

Yang, Charles. 2000. Internal and External Forces in Language Change. Language Variation and Change 12(3), 231-250. 


\section{NOTES}

${ }^{1}$ String-identical versions of (1b) are acceptable where ekki ('not') is contrastively stressed (cf. Angantýsson 2007:239 fn.2). This may be analyzed in accordance with (1a) by placing ekki in a higher structural position (cf. Angantýsson 2007:252). For relevant further discussion, see also Sigurðsson (1986), Bobaljik and Thráinsson (1998), and Thráinsson (2010).

${ }^{2}$ K\&Z (2014:574) link their notion of "richness" of agreement to the "featural distinctions [...] manifested in the smallest (subject) pronoun inventories universally possible." This is criticized by Harbour (2015), who demonstrates the existence of more impoverished pronominal systems. In a reply, Tvica (2017) shows how the 3-person/2-number threshold reemerges under a congenial extension of K\&Z's approach. I have "simplified" the formulation of the RAH in (2) by leaving out reference to the exact construal of richness. Thanks to Erik Petzell, who made me aware of the above complications.

${ }^{3}$ K\&Z (2014:605) formulate a generalization of the RAH to accommodate (I-final) OV languages. The version in (2) is sufficiently precise for the purposes of this paper.

${ }^{4}$ Wiklund et al. (2007:216) explicitly do not exclude correlations between rich agreement and verb placement involving the CP-layer instead of IP.

${ }^{5}$ K\&Z (2014: section 4) adopt a particular approach to argument licensing, which involves recategorizing IP as ArgP. The exact nature of this approach is inconsequential for the present study, so K\&Z's "V-to-Arg" is consistently changed back to "V-to-I."

${ }^{6}$ A more general term such as "dependent V2" may actually be more adequate, if one wants to explicitly avoid prejudging the issue of how exactly V2-clauses attach to their host clauses (cf., e.g., Reis 1997; de Haan 2001).

${ }^{7}$ There are several ways of (potentially) teasing apart these structures. Let me mention the following four: (i) Configuration (3b) triggers island effects for long extraction in Modern Swedish (Holmberg 1986:111), so if extractions from clauses showing the word order pattern in (3) exist, this could be counted as indirect evidence for V-to-I, (3a). (ii) "Left-edge boundary tones" have been found to function as prosodic cues for main clause status in Modern Swedish structures of type (5b) (Roll 2006; Roll, Horne \& Lindgren 2009). (iii) Julien (2015:140) has shown that in Modern Norwegian configurations like (3b), indexicals may behave as if the CP were encoding direct speech. (iv) To the extent that adjunction to I' and IP differs from adjunction to C' and CP, items like (higher) sentence adverbials may be used to distinguish between (3a) and (3b) (cf., e.g., Sigurðsson 1986). 
${ }^{8}$ For Swedish, see Falk (1993).

${ }^{9}$ Standard examples are complements of verbs of saying and belief as well as adverbial clauses introduced by (counterparts of) because, although, and (adversative) while (cf. Wechsler 1991: section 1.2-1.3). In the scope of operators like negation, modals, and (non-declarative) sentence mood, EV2-friendly environments can turn into EV2-hostile ones. The strengths and weaknesses of the "assertion approach" have recently been discussed by, among others, Julien (2015), Gärtner \& Michaelis (2010; to appear), and Wiklund et al. (2009).

${ }^{10}$ Vikner (1995: chapter 4) uses the terms "limited embedded V2" and "general embedded V2," where the latter has led to some misunderstanding (cf., e.g., Hrafnbjargarson \& Wiklund 2009:22). Although the variation within Modern Icelandic has been further confirmed empirically (Angantýsson 2011), it is doubtful whether a simple dichotomy of two "dialects," one displaying $b \mathrm{EV} 2$, the other $n \mathrm{EV} 2$, as originally suggested by Jónsson (1996:39), is correct (Hrafnbjargarson \& Wiklund 2009; Thráinsson 2011).

${ }^{11}$ The exact sources are specified by Sundquist (2002:Appendix A). I have sometimes provided fuller contexts where missing, basing myself on the original sources cited.

${ }^{12}$ Note that the acts performed via ARCs differ from standard assertions in being "secondary" (Chierchia \& McConnell-Ginet 1990:282). According to Koev (2013:6) "appositive proposals [to update the common ground, HMG] are usually decided before main clause proposals." Like presuppositions, they therefore differ from primary assertions in being inaccessible to direct challenging by expressions like No or That's false (see Syrett \& Koev 2015, for possible reversals of these priorities in the case of ARCs in sentence-final position). Importantly, though, ARC-based secondary assertions, (ia), share the "non-triviality" (or "informativity") requirement of standard assertions (cf. Potts 2005:34; Schlenker 2018:8), unlike presuppositions, (ib).

(i) Lance Armstrong survived cancer.

a.\# When reporters interview Lance, who is a cancer survivor, he often talks about the disease

b. And most riders know that Lance Armstrong is a cancer survivor

Thanks to an anonymous reviewer for requesting clarification of these issues.

${ }^{13}$ Locality conditions (cf., e.g., Rizzi 2001) have to be taken into consideration. These concern the status of relative operators in ARCs, the ability of fronted subjects to create "topic islands," and the question of how the two interact. I refrain from going into such matters any further.

${ }^{14}$ Such conjunction-less relatives involving "d-pronouns" allow an alternative variant of (E)V2 without CPrecursion. (i) presents the relevant counterpart of (9).

(i) Hal - dem würde ich unter keinen Umständen vertrauen - fragte nach einem Schlüssel zum Keller 
The result actually is acceptable but it constitutes a clear case of parenthesis. A prosodically integrated variety of German relative-like V2-clauses has been discussed by Gärtner (2001). Although the latter clearly require "assertion-friendly" environments, their distribution differs in striking ways from the one of standard ARCs and the parentheticals in (i).

${ }^{15}$ For the ban on non-subject initial EV2 in ARCs, see Andersson (1975:221 fn.10). Bentzen (2014) provides a brief survey, without, however, distinguishing ARCs from restrictive relatives.

${ }^{16}$ Antomo (2016) makes the interesting proposal that the EV2-hostility of ARCs correlates with their (putative) failure to convey "at-issue" content, definable in terms of being relevant to the/a current "question under discussion" (Roberts 1996). This is closely related to the approach by Wiklund et al. (2009) requiring V2-clauses to be able to carry the "main point of utterance" (MPU). However, these theories face considerable empirical challenges (cf. Julien 2015; Djärv, Heycock \& Rohde 2017). Also, providing a formally sound definition of atissueness that covers sufficiently many clausal environments has proven difficult. The technicalities of this are addressed by Gärtner \& Michaelis (to appear).

${ }^{17}$ Thanks to the editors for making me aware of this.

${ }^{18}$ Note that V-to-v movement creates the preconditions for vP-internal object shift (cf., e.g., Vikner 2017b). The many ramifications of this for the viability of the analysis in (11) remain to be explored.

${ }^{19}$ Such conditionals typically introduce temporary commitments, "for the sake of argument" (Haegeman 2003: section 4.3), often signaled by features echoing previous utterances. At least in languages like German, "premise conditionals" can also be used to signal full-fledged commitments (cf., e.g., Coniglio 2011: section 4.2.4), with the speech act involved here consisting in "ascertaining" (or conceding) a fact rather than asserting a proposition.

${ }^{20}$ This example, cited from Netútgáfan (https://www.snerpa.is/net/isl/kormaks.htm), is from the early 13th century Kormáks Saga (chapter 3), and the translation stems from Collingwood \& Stefánsson (1902). Thanks to Eiríkur Rögnvaldsson for bringing the example to my attention.

${ }^{21}$ Vikner (1995:160) uses the Old Norwegian example in (i), cited after Nygaard (1905:376) to illustrate bEV2.

(i) Gjarna mundi hann hafa viljat drepa hann í fyrstu, ef honum væri pat lofat gladly would he havewanted kill him atfirst, if him.DATwere it allowed 'He would gladly have killed him right away, if he had been allowed to do so.'

However, as pointed out to me by Jóhannes Gísli Jónsson (p.c.), the conditional in (i) can be analyzed as involving a passive construction with honum in Spec,IP and a VP that displays OV-order. 


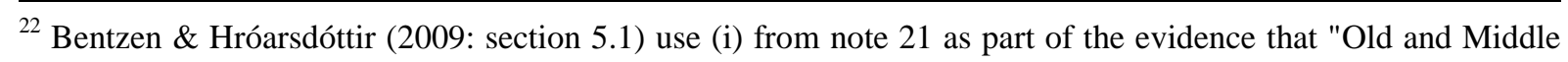
MSc had [...] generalized embedded V2 with subject-verb inversion" (p.127), i.e., bEV2. Additionally, they diagnose V-to-I, which they term "Long non-V2 verb movement" (p.128), for the same group of languages. Curiously, however, offering (14) as evidence from Middle Danish, the authors maintain that this example is an instance of "[v]erb movement across negation and adverbs [...] in non-V2 contexts" (p.128). Yet, for such an assumption to make sense, i.e., for the conditional in (14) to constitute an EV2-hostile environment, a tacit and illicit recategorization of Middle Danish from previously diagnosed $b \mathrm{EV} 2$ to $n \mathrm{EV} 2$ must have taken place.

${ }^{23}$ A som-equative with fronted nu ("now") has also been used by Holmberg \& Platzack (1995:86-87) to illustrate Old Swedish bEV2. Another instance is attested in Old Norse (Faarlund 2004:251). As pointed out to me by the editors, Falk (2007) argues that counterparts of (15) from older stages of Old Swedish could be due to a generalized form of "stylistic fronting" (SF) (cf., e.g., Holmberg 2006). The generalization involves (i) allowing SF in the presence of full subjects, (ii) assuming that subjects are highest on the hierarchy of constituents undergoing SF, and (iii) allowing violations of that hierarchy so that non-subjects can precede subjects in a resulting XVS configuration. The author goes on to speculate that this may apply to the entire range of what is called $b$ EV2-environments in the present study. Unfortunately, I cannot go into the complex ramifications of this interesting proposal here.

${ }^{24}$ Hrafnbjargarson \& Wiklund (2009:37-38) present a promising approach to the $n E V 2$ vs. $b E V 2$ distinction built on an articulated split CP (cf. Rizzi 1997) and independent of matters of verbal agreement. An alternative that relies on the influence of verbal mood is developed by Gärtner \& Eybórsson (to appear).

${ }^{25}$ A related point can be made with respect to the evidence for bona fide V-to-I in Middle English offered by K\&Z (2014:578):

(i) Bycause they come not up and offre

Such adjunct clauses providing reasons - (i) answering the question Why dryve men dogges out of the chyrche? (Roberts 1993:247, 250) - are known to constitute EV2-friendly environments (cf., e.g., Andersson 1975:24).

${ }^{26}$ The same point can actually be made with respect to the Yang-style grammar competition model (cf. Yang 2000) offered by Heycock \& Wallenberg (2013), where EV2-friendly environments confer a competitive advantage to V-in-situ over V-to-I grammars (p.136-137). As far as I can see, the difference between determining these environments within $b \mathrm{EV} 2$ as opposed to $n \mathrm{EV} 2$ lies in speeding up the loss of V-to-I. The exact consequences of this observation remain to be explored. 